\title{
The Political Economy of Meat
}

\author{
Markus Lundström ${ }^{1}$ (D)
}

Accepted: 18 February 2019 / Published online: 27 February 2019

(c) The Author(s) 2019

\begin{abstract}
This paper discusses variegated scholarly approaches to what is here typified as a political economy of meat. Identified as a multifaceted, transdisciplinary and most dynamic field of research, inquiries into the political economy of meat imbricate key issues of social and economic development, across the human-animal divide. While some scholars interpret livestock production as "a pathway from poverty", others observe deepened marginalization and exploitation. The argument raised in this paper is that concise engagement with multiple critical perspectives may facilitate further explorations into the social dynamics that characterize the political economy of meat.
\end{abstract}

Keywords Meat consumption · Livestock revolution · Development ·

Commodification $\cdot$ Speciesism

\section{Food as Political Economy}

Vivid debates on globalized meat consumption now surges in critical food studies. These scholarly discussions entangle, as we will see in this paper, various layers of analysis, thus requiring a transdisciplinary approach to understand the social, political and economic nature of the meat commodity. Overall, systemic analyzes of globalized meat consumption seem to reflect broader inquiries into the political economy of food. Such historical studies of change and continuity in global food commodity chains have typically been conceptualized through the food regime framework, a theoretical approach following a classic economic-historical periodization. The first food regime is here linked to the free trade era between the 1870s and the First World War; and it is replaced by a second food regime, characterized by heavy state subsidizes for domestic food production (Friedmann and McMichael 1989). Following economic de-regulations in the 1970s, and the subsequent consolidation of corporate power over global food chains, political economists identify

Markus Lundström

Markus.lundstrom@ekohist.su.se

1 Stockholm University, Stockholm, Sweden 
an emergent, third food regime (McMichael 2009; Pritchard 1998, 2009). This contemporary food regime is particularly marked by conflict between intensified corporate power and alternative food chain arrangements (Friedmann 2005; McMichael 2005); the political economy of food is accordingly recognized as emblematically contentious (Fine 1994; Koç et al. 2017). In this precise scholarly vein - the study of social, economic and political dimensions of globalized foods-now emerges what we might call the political economy of meat. Scholarly inquiries into that field of research answer, as we will see, to changed patterns in consumption and production of livestock products, observable worldwide over the past four decades. Given the variegated social outcomes entailed by these transformations, studies of the political economy of meat hence articulate an equally diverse — and indeed conflictual—field of research. This paper aims to facilitate critical examination of globalized meat consumption by connecting a variety of scholarly approaches.

\section{Meat Consumption Globally}

Over the past four decades, patterns in global meat consumption have changed dramatically. As indicated in Fig. 1. below, among the 'big three' of animal-derived food products-bovine, pig and poultry meat-we see how pigs and especially chickens are increasingly incorporated into the expanding meat industry. The average yearly meat consumption has, on the global level, risen from 23 to $43 \mathrm{~kg} / \mathrm{year}$ between 1961 and 2013. Furthermore, as we can see in Fig. 2. below, the rise in meat consumption is quite unevenly distributed across the globe; while 'emerging economies' like China and Brazil (though not India) hold the most rapid consumption increase, Europe consumes a disproportionately large amount of animal-derived

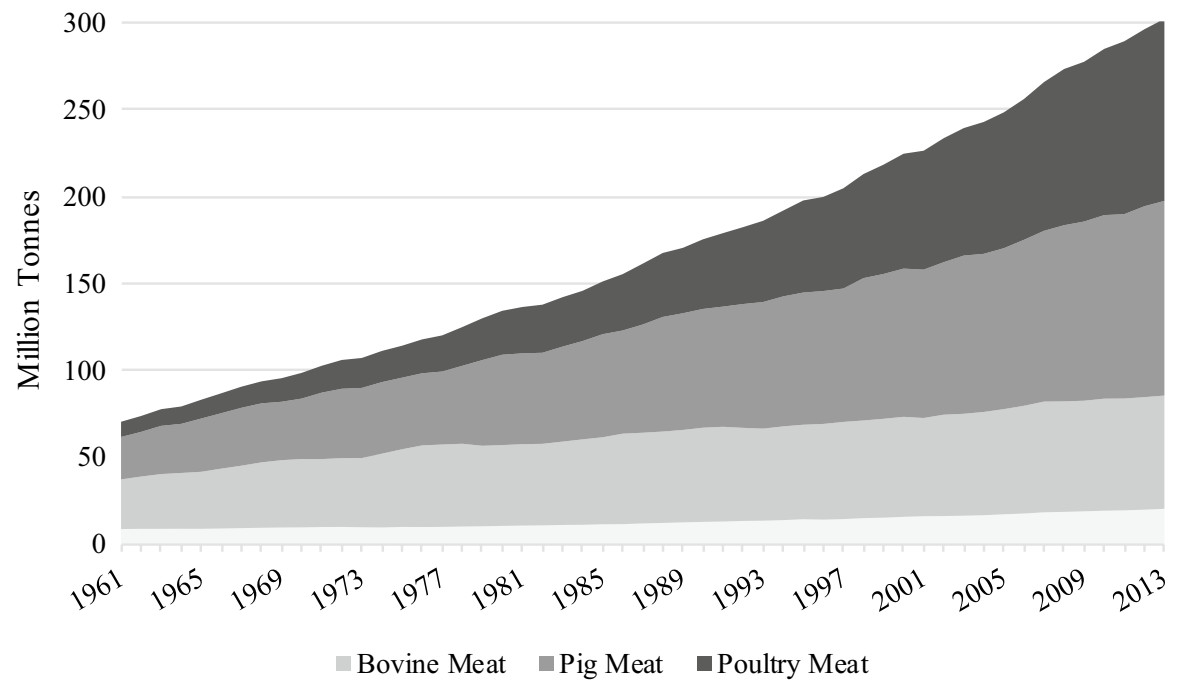

Fig. 1 Global meat consumption, 1961-2013. Source: FAOSTAT database, "Food Supply - Livestock and Fish Primary Equivalent”, accessed 2018-04-11 


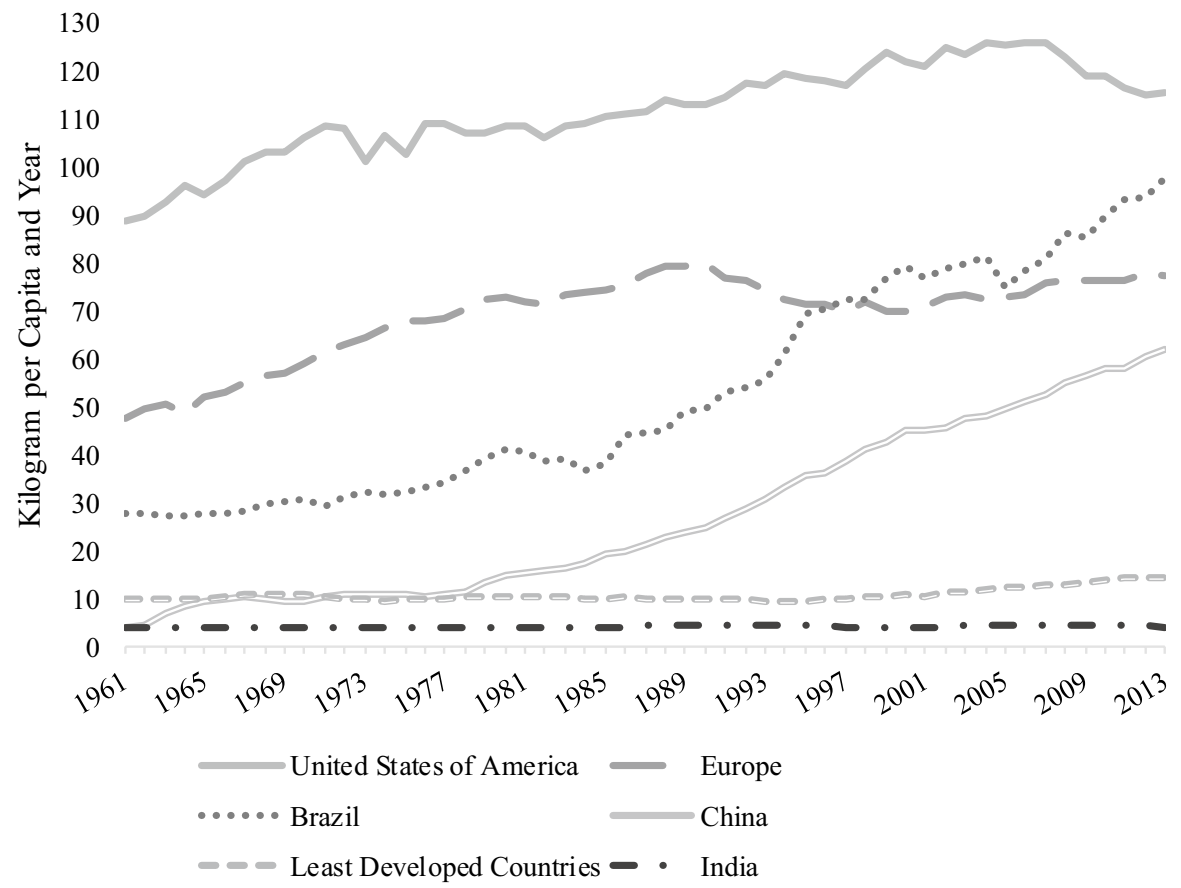

Fig. 2 Regional meat consumption patterns, 1961-2013. Source: FAOSTAT database, "Food Supply Livestock and Fish Primary Equivalent", accessed 2018-04-11

meat, while the US remains the leading meat consumer (Pica-Ciamarra and Otte 2011; Rae and Nayga 2010). At the same time, an average citizen in the world's 50 least developed countries, according to the UN categorization, still consumes less than $15 \mathrm{~kg}$ meat per year.

This economic-historical observation has generated a variety of scholarly interpretations and research agendas; most topical are now the environmental studies linking the livestock sector's alarming relation to greenhouse gas emissions (Hedenus et al. 2014; Steinfeld et al. 2006), freshwater usage (Deutsch et al. 2010), biodiversity loss (Reid et al. 2010), land degradation and deforestation (Dickson-Hoyle and Reenberg 2009). Apart from this environmental topic, the scholarly focus has particularly concerned social outcomes produced by the changed patterns of global meat consumption-in turn fuelling the contentious feature that encapsulates what we accordingly recognize as a political economy of meat.

\section{Meat Production and Rural Development}

The main host of increased livestock production is the so-called developing world. Interestingly enough, this observable development has once again activated the 'revolution terminology' to denote the social significance of this transition, without, most notably, recognizing any political subject of that 'revolution'. In direct 
reference to the Green Revolution launched in the late 1960s, rural development scholars now speak of a Livestock Revolution, a demand-driven economic transition linked to, the argument goes, stronger purchasing power from food consumers in the developing world. The term Livestock Revolution was initially coined in a discussion paper from the International Food Policy Research Institute, as a most deliberate paraphrase to the Green Revolution's establishment of industrial agriculture in Asia and Latin America. By framing the Livestock Revolution as "the next food revolution" (Delgado et al. 1999), the concept underlines how this particular economic transformation-the meat consumption rise-generates imperative opportunities for small-scale farmers in developing countries, since livestock typically provides substantially more net income than do cereals, legumes and vegetables (Kaufmann and Fitzhugh 2005; Nin et al. 2007). The aligned 'development argument' is that marginalized small-scale farmers now have access to previously unreachable global markets through large agri-food companies (Waldron et al. 2003), which therefore provides"a significant opportunity to the rural poor" (Delgado et al. 2003, 20).

However, enhanced markets access also requires, at the production end of the political economy of meat, a rigid adoption of "more capital-intensive technologies" (Nin et al. 2007, 2468). For the small-scale farmer, this generally means submission to a process of vertical integration; agri-food companies-purchasing, processing and distributing animal flesh as meat-rely heavily on standardized on-farm-production (Kaufmann and Fitzhugh 2005; Nin et al. 2007). Livestock Revolution advocates here assert that vertical integration empowers marginalized small-scale farmers to answer high consumer demands, which then generates increased profits for livestock smallholders (Hall et al. 2004; Nin et al. 2007). Standardization procedures furthermore establish uniform nutritional standards that allegedly improves animal welfare (Fraser 2008), as well as food safety for low purchase-power consumers (Bradford 1999; de Haan and Steinfeld 2008; Hall et al. 2004; Kaufmann and Fitzhugh 2005). Furthermore, by construing the global meat boom as a "pathway from poverty" (Brown 2003), Livestock Revolution advocates depict how potentially negative social outcomes ought to be amended by technological advancements (Steinfeld and Gerber 2010), stronger institutions to reduce transaction costs (Narrod et al. 2010), and overall responsible policy making (Dijkman and Steinfeld 2010; Thomas and Rangnekar 2004). This scholarly advocacy hence derives, it should now be clear, from an ideological standpoint that links poverty alleviation to technological development and increased market access.

On that exact note the political economy of meat has also been critically evaluated; cross-disciplinary approaches are now questioning the scholarly belief that "small-scale livestock farmers of developing countries [...] view livestock as a way out of poverty" (Hall, Ehui, and Delgado 2004, 426). Critical scholars point out that such a presumption countervails documented analyzes from farmers themselves; small livestock holders report being highly dependent on agri-food companies (Heffernan 2004), unable to afford the required technical upgrading which often leads to severe indebtedness (Lundström 2011), while at the same time having few options other than submitting to the vertical integration process (Khan and Bidabadi 2004; Millar and Photakoun 2008). Building on the fact that intensified livestock production requires expansive agricultural production for animal feed-approximately one 
third of all grain produced worldwide is now being used for meat production-some scholars also warn that the so-called Livestock Revolution propels an already severe competition for agricultural land (Davis and D'Odorico 2015; Dickson-Hoyle and Reenberg 2009). That is in fact a most traumatic rural transformation that peasant movements, especially in the meat producing context of Brazil, have resisted, decisively, over the past four decades (Lundström 2017; Ondetti 2008).

\section{The Political Economy of Meat}

From a political-economic perspective, then, consumption of meat-of food animals-is inherently contentious; it is a political affair (Neo and Emel 2017). Accordingly, the political economy of meat most notably entails conflict; it comprises resistance to dominant economic arrangements, counter movements that struggle for equality and autonomy across the food chain (Lundström 2018; Williams 1999). Such an array of resistance is commonly conceptualized as food sovereignty, a deliberate critique of the UN-derived concept of food security, aimed at political autonomy, and economic equality, within food commodity chains (Ayres and Bosia 2011; Patel 2006, 2010; Riches and Silvasti 2014). That approach has now become increasingly applicable to studies of meat consumption patterns. On behalf of nothing less than global justice, agrarian scientists have come to disqualify the meat industry as an inefficient way of producing food (Bradford 1999), estimating that, by the year 2050, "the loss of calories by feeding the cereals to animals instead of using the cereals directly as human food represents the annual calorie need for more than 3.5 billion people" (Nellemann et al. 2009, 27). In the same vein, development scholars warn that high-input meat products gradually inflate food prices, meaning that animal protein accessibility relies heavily on monetary assets (de Haan et al. 2001; Rosegrant et al. 2001). This critical observation challenges the presumably demand-driven feature of the so-called Livestock Revolution (Hall, Ehui, and Delgado 2004; Rae and Nayga 2010). Some scholars have in fact pointed out that, when it comes to the political economy of food, little is accomplished by too distinctly separating the forces of consumption and production (Goodman 2002; Holloway et al. 2007), which potentially leads to "continued marginalization of animals and peoples" (Neo and Emel 2017, 11). This line of thought nurtures, in turn, a severe critique, and a direct opposition, to the political economy of meat.

Drawing on a most classic political-economic notion-the process of commodification-critical scholars now theorize the economic and very much cultural transformation of non-human animals into food products (Morton 2017; Neo and Emel 2017; Torres 2007). From this critical perspective, the political economy of meat is fundamentally propelled by generating profit, not food (Gunderson 2013), grounded on ideological bedrocks that establish non-human animals as property (Francione 2004; Wilkie 2010). The increasingly inclusive vision for global justice has in this vein come to encompass all "sentient beings with whose lives our own are inextricably and complexly intertwined" (Nussbaum 2004, 319). This critical line of research specifically sets out to study how "the production, distribution and consumption of meat is encoded within a cultural context" (Williams 1999, 154). With 
the social-historical recognition of meat-eating as deeply variable and contextually embedded (Chiles and Fitzgerald 2018), the political economy of meat surfaces as inseparable from the psychosocial process in which humans come to view animal flesh as edible food (Dowsett et al. 2018; Joy 2010). The entailed theorization accordingly construes the function of speciesism - the hierarchical division between human and non-human animals_-as an ideological scaffolding for the intensified commodification of meat. Hence, questioning the legitimacy of that commodification process (for instance through conscious, dietary changes) clearly adds to the conflictual, dynamic character defining the political economy of meat (DeLessioParson 2017; Glover 2017; Hamilton 2016; Young 2016).

A noticeable development here is the emergent, transdisciplinary research field epitomized as critical animal studies, which has now come to bypass entrenched discussions on the moral status of non-human animals to instead focus on both social and economic aspects of human-animal relations (DeMello 2012). From this scholarly perspective, speciesism denotes the very "complex, dynamic, expansive system that is materially and ideologically imbricated with capitalism as such" (Sanbonmatsu 2011, 21). As a linchpin to the political economy of meat, the speciesist logic more precisely operates, if we follow this critical theory, as a biopolitical instrument; it sways the power to produce, and therefore to destroy (non-human) life. Building on biopolitical theorization on the human-animal relation (Agamben 2004), scholars critically analyze the "biopolitics of food animals and a broader political economy of livestock which aim to modernize and extract greater economic capital out of food animals" (Neo and Emel 2017, 3, 44-49). Hence, by focusing on the social aspects of an "embodied political economy" (Youngs 1999, 2), intersectional approaches aim to uncover innate, discursive linkages between speciesism and parallel logics of domination (Adams 2016 (1990); Lundström 2018; Nibert 2002). Analysing these intersected operations of social differentiation, critical animal studies now document how the speciesist logic_recognized as the very motor of the political economy of meat-is mirrored in parallel, interlocked workings of sexism (Adams 2010; Allcorn and Ogletree 2018; McWeeny 2014; Rothgerber 2013), racism (Monteiro et al. 2017; Morton 2017; Olivier and Cordeiro-Rodrigues 2017; Svärd 2014), and ableism (Schatz et al. 2017).

\section{The Livestock Revolution}

From this critical understanding of the political economy of meat, the labor exploitation, and slaughtering, of non-human animals becomes conspicuously problematic. With the speciesist logic exposed the so-called Livestock Revolution gains, I would argue, additional meaning; it urges us to reconsider its (non-existent) revolutionary subject. It is actually rather tellingly that the Livestock Revolution architects apparently neglect the implicit agency the concept carries, that is: domesticated non-human animals as political subjects. Nevertheless, by utilizing E.P. Thompson's 'history-from-below' approach, it has been documented that animals in human captivity actually perform a great deal of resistance (Hribal 2007, 2010). The political implications of this critical standpoint accordingly stretches from post-humanist 
approaches that endorse minimal human interference with non-human life (MacCormack 2012), to advocacies for democratic inclusion of domesticated livestock into collaborate, human-animal societies (Kymlicka and Donaldson 2014). Disregarding these diverse, political implications, we may recognize how evermore critical perspectives enrich the analysis of workers' realities, all across the global meat factory. By exposing the speciesist logic, and its workings within global capitalism, we arguably become better equipped to critically study - and to change - the political economy of meat.

Open Access This article is distributed under the terms of the Creative Commons Attribution 4.0 International License (http://creativecommons.org/licenses/by/4.0/), which permits unrestricted use, distribution, and reproduction in any medium, provided you give appropriate credit to the original author(s) and the source, provide a link to the Creative Commons license, and indicate if changes were made.

\section{References}

Adams, C. (2010). Why feminist-vegan now? Feminism \& Psychology, 20(3), 302-317.

Adams, C. (1990) 2016. The sexual politics of meat: A feminist-vegetarian critical theory. New York: Bloomsbury Academic.

Agamben, G. (2004). The open: Man and animal. Stanford: Stanford University Press.

Allcorn, A., \& Ogletree, S. (2018). Linked oppression: Connecting animal and gender attitudes. Feminism \& Psychology, 28(4), 457-469.

Ayres, J., \& Bosia, M. (2011). Beyond global summitry: Food sovereignty as localized resistance to globalization. Globalizations, 8(1), 47-63.

Bradford, G. E. (1999). Contributions of animal agriculture to meeting global human food demand. Livestock Production Science, 59(2), 95-112.

Brown, A. G. (2003). The livestock revolution: A pathway from poverty. In The livestock revolution: A pathway from poverty, ed. A. G. Brown. Parkville: The ATSE Crawford Fund.

Chiles, R., \& Fitzgerald, A. (2018). Why is meat so important in western history and culture? A genealogical critique of biophysical and political-economic explanations. Agriculture and Human Values, 35(1), 1-17.

Davis, K., \& D'Odorico, P. (2015). Livestock intensification and the influence of dietary change: A calorie-based assessment of competition for crop production. Science of The Total Environment, 538, 817-823.

de Haan, C., van Veen, T., Brandenburg, B., Gauthier, J., Le Gall, F., Mearns, R., et al. (2001). Livestock development: Implications for rural poverty, the environment, and global food security. Washington, DC: The World Bank.

de Haan, C., \& Steinfeld, H. (2008). Food security in a global economy: Veterinary medicine and public health. In G. Smith, \& A. Kelly (Eds.), The livestock revolution and the developing world (pp. 33-42). Pennsylvania: University of Pennsylvania Press.

DeLessio-Parson, A. (2017). Doing vegetarianism to destabilize the meat-masculinity nexus in La Plata, Argentina. Gender, Place \& Culture, 24(12), 1729-1748.

Delgado, C., Rosegrant, M., Steinfeld, H., Ehui, S., \& Courbois, C. (1999). Livestock to 2020: The next food revolution. Washington, DC: International Food Policy Research Institute.

Delgado, C., Rosegrant, M., \& Wada, N. (2003). Meating and milking global demand: Stakes for smallscale farmers in developing countries. In A. G. Brown (Ed.), The livestock revolution: A pathway from poverty (pp. 13-23). Portville: The ATSE Crawford Fund.

DeMello, M. (2012). Animals and society: An introduction to human-animal studies. New York: Columbia University Press.

Deutsch, L., Falkenmark, M., Gordon, L., Rockström, J., \& and Folke, C. (2010). Water-mediated ecological consequences of intensification and expansion of livestock production. In H. Steinfeld, H. 
Mooney, F. Schneider, \& L. Neville (Eds.), Livestock in a changing landscape. Volume 1: Drivers, consequences, and responses (pp. 97-110). Washington: Island Press.

Dickson-Hoyle, S., \& Reenberg, A. (2009). The shrinking globe: Globalisation of food systems and the changing geograhies of livestock-production. Geografisk Tidsskrift, 109(1), 105-112.

Dijkman, J., \& Steinfeld, H. (2010). Responses on social issues. In H. Steinfeld, H. Mooney, F. Schneider, \& L. Neville (Eds.), Livestock in a changing landscape. Volume 1: Drivers, consequences, and responses (pp. 363-371). Washington: Island Press.

Dowsett, E., Semmler, C., Bray, H., Ankeny, R. A., \& Chur-Hansen, A. (2018). Neutralising the meat paradox: Cognitive dissonance, gender, and eating animals. Appetite, 123, 280-288.

Fine, B. (1994). Towards a political economy of food. Review of International Political Economy, 1(3), 519-545.

Francione, G. (2004). Animals-property or persons? In C. Sunstein, \& M. Nussbaum (Eds.), Animal rights: Current debates and new directions (pp. 108-142). Oxford: Oxford University Press.

Fraser, D. (2008). Toward a global perspective on farm animal welfare. Applied Animal Behaviour Science, 113(4), 330-339.

Friedmann, H. (2005). From colonialism to green capitalism: Social movements and the emergence of food regimes. Research in Rural Sociology and Development, 11, 227-264.

Friedmann, H., \& McMichael, P. (1989). Agriculture and the state system: The rise and decline of national agricultures, 1870 to the present. Sociologia ruralis, 29(2), 93-117.

Glover, M. (2017). Animals off the menu: A racist proposal? In L. Cordeiro-Rodrigues, \& L. Mitchell (Eds.), Animals, race, and multiculturalism (pp. 175-199). Cham: Springer.

Goodman, D. (2002). Rethinking food production-consumption: Integrative perspectives. Sociologia Ruralis, 42(4), 271-277.

Gunderson, R. (2013). From cattle to capital: Exchange value, animal commodification, and barbarism. Critical Sociology, 39(2), 259-275.

Hall, D., Ehui, S., \& Delgado, C. (2004). The livestock revolution, food safety, and small-scale farmers: Why they matter to us all. Journal of Agricultural and Environmental Ethics, 17(4), 425-444.

Hamilton, C. (2016). Sex, work, meat: The feminist politics of veganism. Feminist Review, 114(1), $112-129$.

Hedenus, F., Wirsenius, S., \& Johansson, D. (2014). The importance of reduced meat and dairy consumption for meeting stringent climate change targets. Climatic Change, 124(1-2), 79-91.

Heffernan, C. (2004). Livestock and the poor: Issues in poverty-focused livestock development. In E. Owen, T. Smith, M. A. Steele, S. Anderson, A. J. Duncan, M. Herrero, J. D. Leaver, C. K. Reynolds, J. I. Richards, \& J. C. Ku-Vera (Eds.), Responding to the livestock revolution: The role of globalisation and implications for poverty alleviation (pp. 229-246). Nottingham: Nottingham University Press.

Holloway, L., Kneafsey, M., Venn, L., Cox, R., Dowler, E., \& Tuomainen, H. (2007). Possible food economies: A methodological framework for exploring food production-consumption relationships. Sociologia ruralis, 47(1), 1-19.

Hribal, J. (2007). Animals, agency, and class: Writing the history of animals from below. Human Ecology Review, 14(1), 101-112.

Hribal, J. (2010). Fear of the animal planet: The hidden history of animal resistance. Edinburgh: AK Press.

Joy, M. (2010). Why we love dogs, eat pigs, and wear cows: An introduction to carnism: The belief system that enables us to eat some animals and not others. San Francisco: Conari Press.

Khan, A. A., \& Bidabadi, F. S. (2004). Livestock revolution in India: Its impact and policy response. South Asia Research, 24(2), 99-122.

Koç, M., Bancerz, M., \& Speakman, K. (2017). The interdisciplinary field of food studies. In M. Koç, J. Sumner, \& A. Winson (Eds.), Critical perspectives in food studies (pp. 3-18). Ontario: Oxford University Press.

Kymlicka, W., \& Donaldson, S. (2014). Animals and the frontiers of citizenship. Oxford Journal of Legal Studies, 34(2), 201-219.

Lundström, M. (2011). Dynamics of the livestock revolution: Marginalization and resistance in Southern Brazil. Journal of Sustainable Agriculture, 35(2), 208-232.

Lundström, M. (2017). The making of resistance: Brazil's landless movement and narrative enactment. Cham: Springer International Publishing.

Lundström, M. (2018). "We do this because the market demands it": Alternative meat production and the speciesist logic. Agriculture and Human Values. https://doi.org/10.1007/s10460-018-09902-1. 
MacCormack, P. (2012). Posthuman ethics: Embodiment and cultural theory. Burlington: Ashgate.

McMichael, P. (2005). Global development and the corporate food regime. In F. Buttel \& P. McMichael (Eds.), New directions in the sociology of global development (pp. 265-299). Bingley: Emerald Group Publishing Limited.

McMichael, P. (2009). A food regime genealogy. Journal of Peasant Studies, 36(1), 139-169.

McWeeny, J. (2014). Topographies of flesh: Women, nonhuman animals, and the embodiment of connection and difference. Hypatia, 29(2), 269-286.

Millar, J., \& Photakoun, V. (2008). Livestock development and poverty alleviation: Revolution or evolution for upland livelihoods in Lao Pdr? International Journal of Agricultural Sustainability, 6(1), 89-102.

Monteiro, C. A., Pfeiler, T. M., Patterson, M. D., \& Milburn, M. A. (2017). The Carnism Inventory: Measuring the ideology of eating animals. Appetite, 113, 51-62.

Morton, T. (2017). Humankind: Solidarity with nonhuman people. London: Verso.

Narrod, C., Tiongco, M., \& Delgado, C. (2010). Socioeconomic implications of the livestock industrialization process: How will smallholders fare? In H. Steinfeld, H. Mooney, F. Schneider, \& L. Neville (Eds.), Livestock in a changing landscape. Volume 1: Drivers, consequences, and responses (pp. 269-283). Washington: Island Press.

Nellemann, C., MacDevette, M., Manders, T., Eickhout, B., Svihus, B., Prins, A., et al. (2009). The environmental food crisis: The environment's role in averting future food crises. Birkeland: Unted Nations Environment Programme.

Neo, H., \& Emel, J. (2017). Geographies of meat: Politics, economy and culture. London: Routledge.

Nibert, D. (2002). Animal rights, human rights: Entanglements of oppression and liberation. Lanham: Rowman \& Littlefield.

Nin, A., Ehui, S., \& Benin, S. (2007). Livestock productivity in developing countries: An assessment. In R. Evenson, \& P. Pingali (Eds.), Handbook of agricultural economics, Volume 3: Agricultural development: Farmers, farm production and farm market (pp. 2461-2532). Amsterdam: Elsevier.

Nussbaum, M. (2004). Beyond "Compassion and Humanity": Justice for nonhuman animals. In C. Sunstein, \& M. Nussbaum (Eds.), Animal rights: Current debates and new directions (pp. 299-320). Oxford: Oxford University Press.

Olivier, A., \& Cordeiro-Rodrigues, L. (2017). Racism, speciesism and suffering. In L. Cordeiro-Rodrigues, \& L. Mitchell (Eds.), Animals, race, and multiculturalism (pp. 147-174). Cham: Springer.

Ondetti, G. A. (2008). Land, protest, and politics: The landless movement and the struggle for agrarian reform in Brazil. University Park, PA.: Pennsylvania State University Press.

Patel, R. (2006). International agrarian restructuring and the practical ethics of peasant movement solidarity. Journal of Asian and African Studies, 41(1-2), 71-93.

Patel, R. (2010). What does food sovereignty look like? In H. Wittman, A. Desmarais, \& N. Wiebe (Eds.), Food sovereignty: Reconnecting food, nature \& community. Oakland: Food First.

Pica-Ciamarra, U., \& Otte, J. (2011). The 'Livestock Revolution': Rhetoric and reality. Outlook on Agriculture, 40(1), 7-19.

Pritchard, B. (1998). The emerging contours of the third food regime: Evidence from Australian dairy and wheat sectors. Economic Geography, 74(1), 64-74.

Pritchard, B. (2009). The long hangover from the second food regime: A world-historical interpretation of the collapse of the Wto Doha Round. Agriculture and Human Values, 26(4), 297-307.

Rae, A., \& Nayga, R. (2010)."Trends in consumption, production, and trade in livestock and livestock products. In H. Steinfeld, H. Mooney, F. Schneider, \& L. Neville (Eds.), Livestock in a changing landscape. Volume 1: Drivers, consequences, and responses (pp. 11-34). Washington: Island Press.

Reid, R., Bedelilan, C., Said, M., Kruska, R., Mauricio, R., Castel, V., et al. (2010). Global livestock impacts on biodiversity. In H. Steinfeld, H. Mooney, F. Schneider, \& L. Neville (Eds.), Livestock in a changing landscape. Volume 1: Drivers, consequences, and responses (pp. 111-137). Washington: Island Press.

Riches, G., \& Silvasti, T. (2014). Hunger in the rich world: Food aid and right to food perspectives. In G. Riches, \& T. Silvasti (Eds.), First world hunger revisited (pp. 1-14). Berlin: Springer.

Rosegrant, M. W., Paisner, M. S., Meijer, S., \& Witcover, J. (2001). 2020 Global food outlook. Trends, alternatives, and choices. Washington, DC: IFPRI.

Rothgerber, H. (2013). Real men don't eat (vegetable) quiche: Masculinity and the justification of meat consumption. Psychology of Men \& Masculinity, 14(4), 363.

Sanbonmatsu, J. (2011). Introduction. In J. Sanbonmatsu (Ed.), Critical theory and animal liberation (pp. 1-34). Lanham: Rowman \& Littlefield Publishers. 
Schatz, J. L., George, A., \& Nocella, A. (2017). Introduction: The environment, animals, and disability justice within the liberation movement. In A. Nocella, A. George, \& J. L. Schatz The intersectionality of critical animal, disability, and environmental studies: Toward eco-ability, justice, and liberation (p. xix). London: Lexington Books.

Steinfeld, H., \& Gerber, P. (2010). Livestock production and the global environment: Consume less or produce better? Proceedings of the National Academy of Sciences of the United States of America, 107(43), 18237-18238.

Steinfeld, H., Gerber, P., Wassenaar, T., Castel, V., Rosales, M., \& de Haan, C. (2006). Livestock's long shadow: Environmental issues and options. Food and Agriculture Organization of the United Nations (FAO).

Svärd, P.-A. (2014). Slaughter and animal welfarism in Sweden 1900-1944. In M. Wissenburg, \& D. Schlosberg (Eds.), Political animals and animal politics (pp. 135-149). London: Palgrave Macmillan.

Thomas, D., \& Rangnekar, D. (2004). Responding to the increasing global demand for animal products: Implications for the livelihoods of livestock producers in developing countries. In E. Owen, T. Smith, M. A. Steele, S. Anderson, A. J. Duncan, M. Herrero, et al. (Eds.), Responding to the livestock revolution. Nottingham: Nottingham Univeristy Press.

Torres, B. (2007). Making a killing: The political economy of animal rights. Edinburgh: AK Press.

von Kaufmann, R. R., \& Fitzhugh, H. (2005). The importance of livestock for the world's poor. In C. Scanes, \& J. Miranowski (Eds.), perspectives in world food and agriculture (pp. 137-160). Iowa: Iowa State Press.

Waldron, S., Brown, C., \& Longworth, J. (2003). Transforming lives with livestock-based agri-business. In A. G. Brown (Ed.), The livestock revolution: A pathway from poverty? (pp. 27-39). Portville: The Crawford Fund.

Wilkie, R. (2010). Livestock/deadstock: Working with farm animals from birth to slaughter. Philadelphia: Temple University Press.

Williams, M. (1999). The political economy of meat: Food, culture and identity. In G. Youngs (Ed.), Political economy, power and the body: Global perspectives (pp. 135-158). Houndmills: Palgrave Macmillan.

Young, K. (2016). Herbert's herbivore: One-dimensional society and the possibility of radical vegetarianism. New Political Science, 38(4), 547-560.

Youngs, G. (1999). Introduction. In Gillian Youngs (Ed.), Political economy, power and the body: Global perspectives (pp. 1-10). Houndmills: Palgrave Macmillan.

Publisher's Note Springer Nature remains neutral with regard to jurisdictional claims in published maps and institutional affiliations. 